\title{
SECURITY ARRANGEMENTS FOR THE 2011 ELECTIONS
}

\section{Osisioma B C Nwolise}

Dr Nwolise is Senior Lecturer and Acting Head, Department of Political Science, University of Ibadan e-mail: osynwolise@yahoo.com; politicsibadan@gmail.com

\begin{abstract}
This article reviews the security arrangements that undergirded the relative peace and order that characterised the 2011 general elections. It explores the security guarantees for the various phases of the election and argues that the elaborate security arrangements not only ensured relative peace but contributed to the credibility of the elections. It argues, further, that the neutrality of the security agencies reflects the commitment of the president to ensuring free and fair elections and therefore the uncompromised use of security agencies. The agencies were therefore able to cooperate with each other and with the electoral management body to support the electoral process. The article also suggests possible improvements in the security arrangements for future elections.
\end{abstract}

\section{INTRODUCTION}

Survival is not just an important value in the contemporary world, it is the most important value, whether for an individual, a group, or a nation. Hence the popular assertion that self-preservation is the first law of nature. Anxiety about the security of a nation has been a long-standing 'diet' of political leaders and is as old as the nation-state itself (Brown 1982) and the fundamental issue has always remained the survival of the nation (Brennan 1962).

The issue of security has become even more important recently, with domestic forces easily able to align with external enemies to cause outrageous national calamities, as is the case with the Boko Haram in Nigeria, or where external elements use domestic platforms to achieve the type of destructive goals they did in America on 11 September 2001. Thus, though terrorism (national or international) has raised current anxiety levels over national security to unprecedented levels, security has always been an issue of great concern. Adam 
Smith (quoted in Whynes 1979, p 1) as far back as the $18^{\text {th }}$ century argued that the provision of national defence from the taxpayers' money is the 'first duty of the sovereign'. Fischer \& Green (2004, p 21) remind us what security implies and of its original goals of protecting citizens and kings as well as its contemporary tasks in the face of computer crimes and world terrorism. In their words:

Security implies a stable, relatively predictable environment in which an individual or group may pursue its ends without disruption or harm and without fear of disturbance or injury ... Thus, in medieval England there were programmes to clear bush and other concealment on either side of the King's roads as a precaution against robbers, and to protect citizens from night thieves there were night watchmen ... The introduction of high-tech systems and computers has changed the nature of the job of the $21^{\text {st }}$-century security professional. Security today must be directed toward modern problems including computer crime and world terrorism.

The United Kingdom, in preparing for the London Olympics, has budgeted millions of pounds for security. In addition, the navy, police and airforce carry out daily exercises designed to keep the nation secure before, during, and after the games. The USA has, since 11 September 2001, reorganised its security machinery, creating a new Department of Homeland Security, which is the largest department in the country today, consuming billions of dollars annually. These examples show the lengths to which nations go to ensure national security, especially in these days of terrorism, kidnapping, piracy, and suicide bombings.

As Nigeria prepared for the 2011 general elections there were visible signs of security threats, as highlighted in detail below. Among these were Boko Haram bombings in Borno, godfathers and their thugs, the assassination of political opponents and the creation by several politicians of private 'armies'. In a situation where high profile politicians each had between five and ten personal guards (excluding the several thugs who could be mobilised at will), 600000 politicians spread over 36 states of the federation and the Federal Capital Territory meant 6000000 thugs, a number that far outweighs the number of defence and security personnel in the country.

Thus, there was a need to provide security for citizens, politicians, electoral campaigners and contestants, officials of the Independent National Electoral Commission (INEC), electoral materials, voters, votes cast, polling units, as well as collation centres. This article examines the security arrangement for the 2011 elections. The essence is to evaluate the arrangement and highlight necessary improvements for better performance in the future. 
The discourse benefits from the social contract theory expounded by JeanJacques Rousseau (see Cress 1987) and the frustration-aggression theory of Sigmund Freud (1939) and Dollard, Doob, Miller, Mowrer \& Sears (1939). National governments have obligations to citizens, the most outstanding of which is security. In return, citizens surrender some of their rights to the state.

One right they do not surrender is the right to participate in the democratic governance of the state, especially to elect its leaders, and the frustration of this right may engender violence and insecurity. Unscrupulous politicians, especially the mercantile godfathers in pursuit of their undemocratic political plans and ambitions, may unleash mayhem on the people. The incumbent government may deploy the defence and security apparatus against the people in an attempt to ensure that its favoured candidates win elections. Where such a move is suspected the people themselves may organise to protect their vote and to checkmate the state.

Akzin (1960, pp 706-8) asserts that elections have both technical and social relevance. The technical relevance lies in the process by which an office is assigned to a person or contestant through an act of volition involving the simultaneous expression of many people's choice. The social relevance lies in participation in the electoral process and the achievement of governance by consent. This consent, as Mayo (1960, p 73) puts it, imbues an elected government with legitimacy, as the main 'purpose of the whole electoral process is to produce a government invested with legitimacy'.

There was more to the 2011 elections in Nigeria than merely assigning candidates to positions, getting the consent of the people, and imbuing the emergent government with legitimacy. The elections provided a platform for testing President Goodluck Jonathan's avowed commitment to preside over free, fair and credible elections and also INEC's claim to have the will and capacity to organise credible elections.

\section{PRE-ELECTION VIOLENCE AS IMPETUS FOR THE SECURITY ARRANGEMENTS FOR THE ELECTIONS}

President Olusegun Obasanjo's declaration that the 2007 election was a 'do-or-die affair' for the People's Democratic Party (PDP) set the tone for the violence and fraud that characterised that election. Thus Nigerians welcomed President Umaru Musa Yar'Adua's admission during his inauguration speech that the elections had been tainted by fraud and his efforts to reform the electoral process.

However, the reform of the electoral process was retarded by his protracted ill health, long absence from the country and eventual death. On assuming office as president, Yar'Adua's successor, Goodluck Jonathan, assured the country of 
his desire to carry out electoral reforms. He reassured Nigerians that their votes would count and that he would ensure free and fair elections in 2011.

With the re-delimitation of constituencies and wards effected even before Professor Attahiru Jega was appointed chairman of INEC, the processes of the 2011 election began with the registration of voters from 15 January 2011, in line with the Electoral Act of 2010. To ensure that the exercise was made easy for prospective voters the government closed schools and used them as venues for the exercise.

Although there was initial apathy, and logistical challenges, including the late arrival of materials, the registration exercise was successful and ended with the display of the voters' register. However, during the exercise there were serious security challenges in some parts of the country where incidents of violence intensified with the commencement of campaign rallies. Clashes between the supporters of different parties led to the death of several people and the destruction of property.

For example, there were bomb blasts in Jos on the first day of the voter registration process, although it is not clear whether the incidents were linked to an attempt to disrupt the registration exercise (Sunday Tribune, 16 January 2011, $\mathrm{p}$ 11). In a major violent incident in Uyo, Akwa Ibom State, 10 people were killed and more than 5000 vehicles (worth N2-billion) belonging to the Akwa Ibom State government were burnt as supporters of the PDP and the Action Congress of Nigeria (ACN) clashed (Nigerian Compass, 24 March 2011, pp 1, 50, 51). Violence that broke out in Ekiti State on 23 March led to the killing of two PDP members in Omuo-Ekiti, and in Ondo State more than 11 people were injured in Akure when PDP and Labour Party (LP) supporters clashed in various areas of the town.

At President Jonathan's campaign rally in Port-Harcourt on Saturday 12 February 2011, a stampede resulted in 10 people being trampled to death (Awuzie 2011,21). The police picked up eight ammunition shells at the venue of the rally (Chukwura 2011, p 7). In Anambra State the campaign trains of Senator Annie Okonkwo of the Accord Party, and Dr Chris Ngige of the ACN were ambushed by thugs sponsored by another party and in Oyo State hoodlums believed to be members of the National Union of Road Transport Workers abducted Julius Olaoye, a leader of the Accord Party.

In Ekiti and Ondo states, according to press reports, two people were killed, while irate party supporters burnt down the PDP and Congress for Progressive Change (CPC) secretariats in Hadejia, Jigawa State. In Benue State party thugs beat to death the driver of Lawrence Onoja, who was the ACN's senatorial candidate and who had, earlier in the month, been wounded in an assassination attempt. In Kebbi State, thugs attacked Alhaji Adamu Aliero, former governor of the state, and Alhaji Abubakar Malam, who was the CPC's candidate for governor. In these attacks one person died and eight vehicles and two houses were set alight (The 
Guardian, 27 March 2011, p 16). Willy Eya (2011, p 65) attributed the violence to the persistent high level of intolerance and the high stakes of politics and predicted that things would get worse. In his words:

Characteristic of elections in Nigeria, stories from the states are already unsettling with reports of varying degrees of harassment, intimidation, thuggery and violence being the order of the day. Already, several lives have been reportedly lost in violence linked to political party primaries and election campaigns since November last year. Analysts argue that based on precedent, the level of violence is expected to increase in the days leading up to and during the elections. As it appears the bloodletting that has been a major characteristic of electioneering across the land is not likely to end soon.

The pre-election political situation left little hope that the elections would be peaceful. Many felt that the security agencies were not up to the task and that the elections were not likely to be credible. This point was made in an editorial in The Guardian (27 March 2011, p 16):

The renewed violence of the past weeks, ostensibly during political campaigns, raises again, questions as to the level of the nation's preparedness for the elections. The major posers include whether any election can indeed be conducted under the current atmosphere of fear; and whether confidence can be reposed in the police and other law enforcement agencies to prevent or handle violent crises.

On 23 March, after a Federal Executive Council meeting, President Jonathan called for an immediate halt to the violence (Sunday Sun, 27 March 2011, p 6). On 31 March, two weeks before the first in the series of elections, the then inspector general of police, Hadiz Ringim, reorganised and redeployed commissioners of police in the states for the period of the elections. He ordered senior police officers to ensure that the elections were free, fair, peaceful and credible by arresting all troublemakers (Agbambu 2011, p 4). On the same day, the Edo State Police command announced the arrest of two people suspected of having shot and killed Senator Ehigie Uzamere's police orderly in an attack on the senator on 19 March (Nigerian Tribune, 1 April 2011, p 3).

Also on 31 March the chief of army staff, Lt General Azubuike Ihejirika, toured army divisions and warned political thugs against any attempts to disrupt voting, warning that 'the military will be armed and ready to contribute its best towards supporting the civil authority' (Olisah 2011, p 2). This show 
of commitment to putting a stop to the violence was critical to the security arrangements that undergirded the elections. The high level of violence, tension, anxiety and fear that existed in the country between June 2010 and March 2011 made it necessary for extra security measures to be put in place if the elections were to be free, fair, credible, and non-violent. Without such measures, the 2011 elections would be no better than those of 2007, which were marred by violence and rigging (Suberu 2007).

\section{SECURITY MEASURES}

As noted above, the period before the voting days was characterised by violence. Thugs, assassins and arsonists had almost free rein. There were no special arrangements for security during the campaign period. However, special security measures were put in place to ensure free, fair, orderly, secure and credible elections throughout the voting period, which began with the National Assembly elections of 9 April and ended with the gubernatorial elections on 26 April.

Security was concentrated on matters concerning the ballot and voting. This article focuses on eight key areas.

\section{Security of the voters' register}

The voters' register is one of the most critical ingredients of any election. Without it, voting cannot take place even if all other elements are available in abundance. The register can also be a source of rancour and litigation that can mar an election, as it is possible for a candidate to be cheated out of a position by the systematic elimination of the names of his supporters from the list and their replacement with fake names or the names of those who will favour the opponent.

Thus, the security of the voters' register is crucial. INEC made solid arrangements for the compilation of the 2011 register, using digital data capturing machines instead of manual registration. These captured not only the names of voters but also their pictures (passport) and finger prints. This eliminated the possibility of individuals registering more than once.

Public education programmes warned against multiple registration and about registration by underage children (younger than 18) and foreigners. Law enforcement personnel were instructed to assist INEC staff to stop such illegal registrations.

Once the registration exercise ended the names were displayed for correction and public complaint and reports of irregularities, to ensure that those who were registered were qualified to hold and use the franchise, especially in terms of age and citizenship. 


\section{Security of electoral materials}

Sensitive electoral materials such as ballot papers and result collation sheets were printed outside Nigeria and INEC engaged the Nigerian Air Force to distribute them to safe points in states, while the navy transported them on rivers and creeks to difficult terrains (The Guardian, 27 March 2011, p 70).

Where necessary, electoral materials were guarded by army and police personnel from the date of transportation through storage, to the day they were used, hence it was not possible, as it had been in the past, for people to break into stores and steal them or to hijack ballot papers in transit for rigging purposes.

\section{Security of INEC offices, officials and staff}

INEC offices, officials, staff and equipment were well protected by military and police forces throughout the voting period. Given the incidents of bombing, assassination and kidnapping in the country the 'officers and men of the Antiterrorism Squad (ATS) of the Nigerian Police Force took over the national headquarters of INEC in Abuja as part of security measures' (Olatunji \& Usigbe 2011, p 1). INEC's state headquarters were also well protected, with its personnel, especially the members of the National Youth Service Corps (NYSC), safeguarded by security agents deployed at polling booths and collation centres.

\section{Security of the national borders}

Nigeria had had the experience of illegal immigrants participating in riots in the country. The Maitatsine insurgents of the 1980s came into Nigeria through the porous borders with Cameroon. During the registration period some foreigners were found to have slipped into the country to register.

Thus, to prevent aliens from trooping into the country to vote, especially in the North, from Chad, Niger and Cameroon, there was extra vigilance and security at the country's national borders. The Nigerian Immigration Service was involved and the borders were closed on significant days, one of these being 15 April, the day before the presidential election (Nigerian Television Authority Network news, 15 April 2011).

\section{Security of the voters}

Prior to the first voting day (9 April), government, INEC and the security forces reassured Nigerian voters of their security. The real threats to voters since 1959 had been political thugs used by unscrupulous politicians, mercantile godfathers and power-hungry party chiefs to intimidate political opponents and chase away 
voters, giving the thugs and their paymasters the opportunity to rig elections by snatching ballot papers and ballet boxes, stuffing ballot boxes with thumb-printed ballot papers or exchanging empty ballot boxes at polling booths with boxes that had already been filled.

Among the measures put in place was a restriction on vehicular movement during voting hours, with those who violated the restriction order being arrested. For the presidential election the restrictions were in place from 10pm on Friday 15 April until 6pm on Saturday 16 April.

Also, in some states, such as Oyo State, the police command summoned suspected thugs for 'discussions' about peaceful elections a few days before the beginning of voting for the National Assembly (NASS) elections (Waheed 2011, $\mathrm{p}$ 12). In Ondo State the police went further, compelling suspected thugs in the 18 local government areas to sign an undertaking to maintain the peace during the voting period (Waheed 2011, p 12).

Arrangements made to secure the roads and streets also enhanced the security at the polling booths and collation centres.

\section{Security of the streets}

Security in the streets was tight on all voting days, especially on the days of the presidential election. The prohibition of movement ensured peaceful roads, making it easy to deal with isolated cases of threats to peace, law, order and security. This author remembers being at the Nigerian Television Authority studios with a top police officer during the National Assembly elections when the officer received a phone call informing him that thugs were creating problems at a spot in Ibadan town. He ordered the movement of lorry loads of mobile police to the spot and, within minutes, the place was quiet.

Military personnel were stationed at strategic junctions, carrying out stop and search operations. In some areas personnel from the Nigerian Police, Nigerian Immigration Service, Nigerian Customs Service, Nigerian Prisons Service, Federal Road Safety Corps, and Civil Defence Corps manned roadblocks with the soldiers. In addition, police personnel patrolled the roads and streets giving confidence to voters, while frightening away the thugs and the godfathers.

More than 370000 police officers were deployed by police headquarters in Abuja for the elections (Sunday Sun, 27 March 2011). Soldiers and security personnel enforced restriction orders on movement, while air force and police helicopters conducted aerial surveillance. There was active cooperation among the defence and security agencies and their personnel throughout the voting period - the first time in Nigeria's history that there had been such a massive turnout and cooperation among all the defence and security forces in the country. 
These arrangements caged the thugs and their paymasters (godfathers, party stalwarts and incumbent political leaders) and all brands of election riggers and anti-democratic forces.

\section{Security of the ballot}

The vote is the most critical element of an election. It is what links the electorate, the candidate and the post itself. It is the tool with which the voter expresses his or her consent to be governed by whoever is elected into office. It confers democracy and it is with the vote that the people make or unmake (enthrone or dethrone) leaders. Thus, the security of the vote is of the utmost importance.

To ensure this security in the 2011 elections INEC and some political parties used radio and television to urge voters not to sell their franchise (registration cards). They were told that the election was their opportunity to vote in good leaders and vote out bad ones. Thus they were told to use their ballot wisely.

While the INEC chair, Professor Attahiru Jega, and some political parties urged voters not to go home after voting but instead to remain at the polling booth to protect their vote until after the count and declaration of results, the then inspector general of police emphasised the need to avoid crowding polling stations and instructed people to vote and go home.

Professor Jega advised voters to vote and stay at a safe distance from the polling station, 'provided they are calm and peaceful', warning that 'anybody who tries to be rowdy or cause confusion can be picked from the voting area by the law enforcement agencies' (Abubakar \& Aliu 2011, p 7). Jega also stated that voters could take with them to the polling stations cameras and mobile phones with camera facilities which could capture instances of rigging or scenes of violence.

These security arrangements gave people hope and confidence that the 2011 elections would be different from previous elections and encouraged them to go out and vote.

\section{Security of the people's verdict and the integrity of the elections}

The people's verdict constitutes their democratic choice. It is the golden trophy in the struggle between politicians and the electorate. What happens to the collective verdict of the people determines the integrity of an election. Since 1959 there has been a suspicion that the people's choice in Nigerian elections has always been discarded, while politicians determined who was declared the winner. It is such undemocratic action that, after the 1965 elections, precipitated the revolt in the western region which led to the first military coup, on 15 January 1966.

To ensure the security of the people's verdict INEC recruited a patriotic 
segment of the citizenry - the NYSC members - as its ad hoc field staff to man the polling booths, instead of the civil servants who had previously been used for the purpose. INEC also engaged the services as returning officers of serving and retired university lecturers, especially professors and vice-chancellors, who were perceived as men and women of integrity who have, over the decades, built reputations they must protect. The fact that Professor Jega was a former chairman of the Academic Staff Union of Universities, and former vice-chancellor of Bayero University, Kano, facilitated the recruitment of the academics.

An innovation introduced by INEC was a 'Situation Room', in which officials were able to receive text messages, telephone calls and e-mails and check Facebook and Twitter for reports of emergencies and irregularities. With information from these sources INEC was able to control situations in the field, sending electoral materials to where they were needed and correcting field officials whose actions might jeopardise the credibility of the elections.

INEC administered an 'oath of neutrality' to all ad hoc staff and warned that any member of staff caught misbehaving would face the full wrath of the law. Jega emphasised that the commission would cancel on the spot any election in which the number of ballots was greater than the number of accredited voters because 'such outcomes would have been under serious questions or such would have been fraud' (Quoted in Abubakar \& Aliu 2011, pp 1, 7).

In the end, INEC ensured that the results were, without doubt, the people's verdict.

\section{EVALUATION OF THE SECURITY ARRANGEMENTS}

The security arrangements put in place by government, INEC and the defence and security agencies focused specifically on election days, which probably accounts for the fact that there was a significant amount of violence during the period leading up to the elections. The pre-election period was characterised by the activities of thugs, godfathers, assassins, arsonists and even terrorists. This should not have been so. Tight security should have been provided once the nation entered the electoral season, from the registration process through the campaign period to the announcement of the results. This is a lesson for the future. Campaigning is a crucial aspect of elections - the time when political parties educate, enlighten and mobilise the electorate for the vote. Once violence mars the campaign period voting will be adversely affected.

Because security for the 2011 elections was concentrated on the voting period the post-election violence that greeted the announcement of the presidential election results seems to have caught government and security agencies unawares. 
There is no doubt that the security arrangements for the election days were well planned and enforced, but there is room for improvement. Even during the voting period there were cases of security breaches. For example, despite the heavy security in major streets and roads, bomb blasts rocked a polling unit in the Unguwa Doki area of Maidguri, injuring 10 people on 9 April (Sunday Champion, 10 April 2011, p 3). On the same day eight people died and 56 were injured when thugs stormed a police station in the headquarters of the Shani Local Government Authority in Borno State (Leadership on Sunday, 10 April 2011, p 1).

In Bono, Kebbi, Delta, Osun, and Ogun states violence was experienced on the first day of voting. The INEC office at Abeokuta was set alight, while several people were arrested in Kwara State with false voters' cards. In Imo State, ballot boxes were snatched on 9 April, while 20 NYSC members died in bomb explosions in Suleja on the same day (Leadership on Sunday, 10 April 2011, p 11).

Bomb blasts in the INEC office and collation centre at Galadima Junction in Maiduguri between 7 and 8 pm on 15 April were regarded as an attempt to discourage voters from going to the polls the following day.

On 26 April soldiers arrested 60 political thugs in six buses in Isukwuato, Abia State. (ThisDay, 17 April 27, p 9), while 133 more were arrested in Kebbi State on the same day; six ballot boxes were snatched in Kano State and in Osun State soldiers arrested a PDP chief and his thugs (ThisDay, 27 April 2011, p 11). In Ughelli (Delta State), six thugs were shot dead in a fight with police while trying to snatch ballot boxes (Sunday Champion, 10 April 2011, p3). Thus, despite the heavy security arrangements, there were pockets of security breaches even during the voting period. They were, however, not enough to stop voting, or to prevent the nation from achieving a successful free, fair and credible election.

As the leader of the European Union Monitoring Group in Nigeria, Peterie Alojz, noted, generally the election was carried out in a peaceful and orderly manner and there was large turnout of voters. He was also pleased with the security arrangements (monitored on NTA Nation-wide Report, 'Nigeria Decides', 16 April).

\section{CONCLUSION}

The security arrangements for the 2011 elections were the best in Nigeria's history. Thugs and godfathers were caged; throughout the country pregnant women, disabled persons, some of who came in wheelchairs, and aged people were able to vote confidently, peacefully and securely and local and foreign observers were impressed with the security arrangement. The synergy of the defence and security agencies - military, police, customs, immigration, prisons, civil defence, and road safety worked very well and encouraged voters to turn out. 
One factor in this positive record was President Goodluck Jonathan's commitment to ensuring a credible election and his choice for chair of INEC reflected this commitment. Professor Jega managed INEC and the election personnel (permanent and ad hoc) in a manner that transformed public perceptions of the possibilities of the institution. At important points during the electoral process he employed the skills of NYSC members and academics in ways that strengthened the credibility of the elections. The disposition of the president, who appoints the leadership of INEC, is critical in this matter.

The cooperation of all defence and security agencies in working for the common good was also an innovation - in the past security agencies were used to cover up election rigging. The synergy among them shows that Nigeria's security personnel will always work as strong bastions of democracy once the political leadership is democratic and the security agents are equipped and funded to perform. Security agents mirror the political leadership. If a soldier or police officer serves a democrat he or she will be a democrat, but if the political leader is a dictator, the soldier or police officer will be an oppressor of the people.

The 2011 elections prove that the problem with elections in Nigeria since 1959 has been non-democratic political leaders who rigged the process. We are inclined to suggest that INEC should begin now to prepare for the 2015 elections, starting with demanding the necessary changes to the Constitution and electoral laws.

Nigerian politicians must build upon the gains of the 2011 elections and resolve never to allow a return to the days of 'do-or-die' elections. The task now is to consolidate and sustain democracy. For 2015, political parties should begin to draw on ideology and focus their campaigns on issues not on personalities. Candidates must also have the humility and patriotism to participate in public debates during campaigns. This will reduce the intensity of electoral competition that often transforms it into warfare.

\section{— REFERENCES}

Abubakar, M \& A Aliu. 2011. 'INEC Administers Oath of Neutrality On Staff'. The Guardian, 27 March.

Agbambu, C. 2011. 'IGP Reads Riot Act On Election'. Nigerian Tribune, 26 March. Akzin, B. 1960. 'Election And Appointment'. American Political Science Review 3. Awuzie, A. 2011. ‘Go To Rallies And Die'. Daily Sun, 17 February.

Eya, W. 2011. 'April Polls: On Your Marks ... Set ...'. Sunday Sun, Lagos, 27 March.

Bassey, A, R Ogbonnaiye, K Olayemi, B Okeowo, D Akinjogunla, A Oyetunji \& 
G Isenyo. 2011. 'N2 billion Vehicles Lost To Akwa Ibom Violence'. Nigerian Compass, 24 March.

Brennan D. 1962. 'Setting The Goals of Arms Control'. In D Brennan (ed). Arms Control, Disarmament And National Security. New York: Brazillier.

Brown L. 1982. 'An Untraditional View of National Security'. In A Reichart (ed). American Defence Policy. Baltimore, MD: Johns Hopkins University Press.

Chukwura, H. 2011. 'Rally Tragedy: Police Pick 8 Ammunition Shells From Venue'. Daily Sun, 17 February.

Cress, D (ed). 1987. Writings of Jean-Jacques Rousseau. Indianapolis: Hacket Publishers.

Dollard, J, L Doob, N E Miller, O H Mowrer \& R R Sears. 1939. Frustration and Aggression. New Haven, CT: Yale University Press.

Freud, S. 1939. 'Thoughts For The Times On War And Death'. Collected Papers of Sigmund Freud vol 4. New York: Basic Books.

Fischer, R \& G Green. 2004. Introduction to Security. London: ButterworthHeinemann.

Guardian, The, 27 March 2011.

Mayo, H. 1960. An Introduction to Democratic Theory. New York: Oxford University Press.

Nigerian Tribune, 1 April 2011.

Oderemi, K. 2011. 'Be Vigilant, Shine Your Eye'. Nigerian Tribune, Ibadan, 26 March.

Olatunji J \& L Usigbe. 2011. 'Election Violence: Anti-Terrorism Squad Takes Over INEC HQ'. Nigerian Tribune, 24 March.

Olisah, U. 2011. 'April Polls: Chief of Army Staff Warns of Dire Consequences For Hoodlums'. Nigerian Tribune, 1 April.

Suberu, R. 2007. 'Nigeria's Muddled Elections'. Journal of Democracy 18(4).

Sunday Sun 'Comment'. 2011. 'Checkmating Pre-election Violence'. Sunday Sun, Lagos, 27 March.

Whynes, D. 1979. The Economics of Third World Military Expenditure. London: Macmillan.

Waheed, A. 2011. 'Oyo CP invites Suspected Thugs'. Nigerian Tribune, 1 April. 